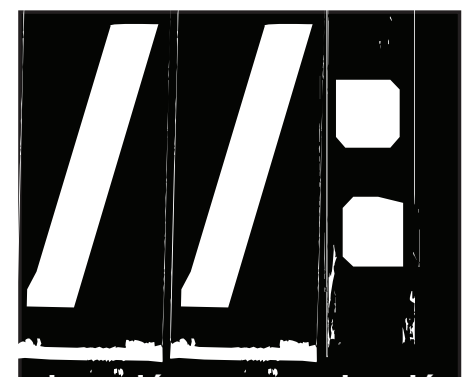

\title{
EL VINO DEL ESTÍO
}

\section{Autor: Ray Bradbury}

Año: 1957 / 1996

Editorial: Minotauro

Localidad: Barcelona

educación y comunicación

17:121-122 Nov. 2018

Daniel Gómez Ramos

Universidad de Barcelona

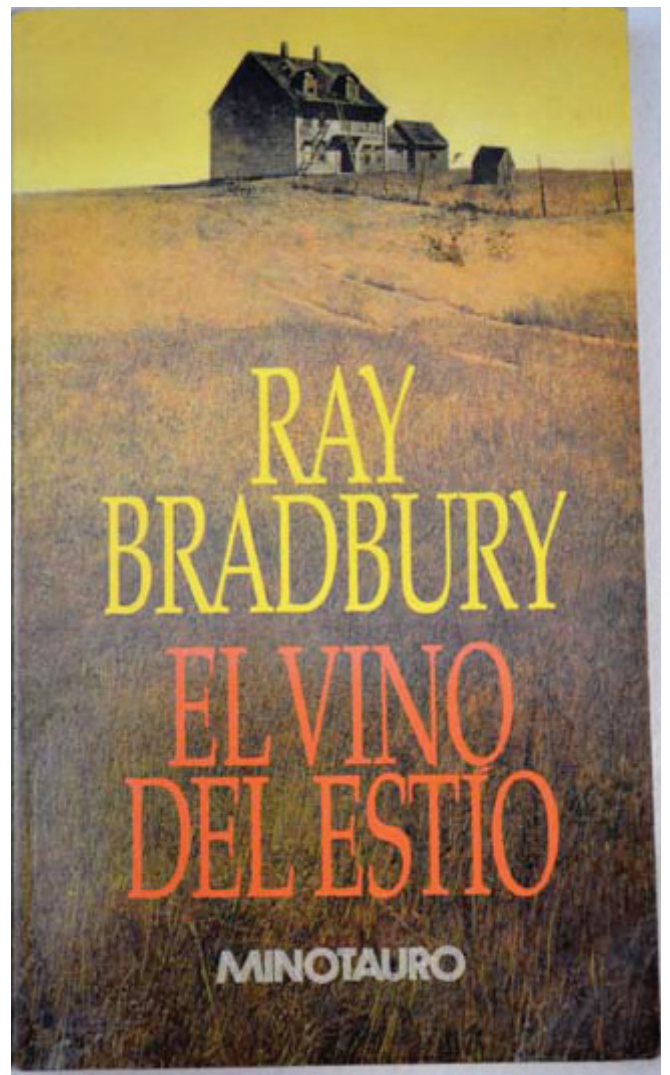




\section{II: Educación y comunicación en los mundos de fantasía y ficción}

$E$

vino del estío no es sólo la crónica de un verano lleno de anécdotas prodigiosas. No es simplemente el retrato de un pequeño y supuestamente ordinario pueblo. No bastaría con decir de estas páginas que narran la historia de dos niños que aprenden el acontecimiento de estar vivos. Ray Bradbury se encarga de hacer que tres calurosos meses de 1928 condensen algunos saberes fundamentales del legado humano. $Y$ es que basta con observar con cariño y escuchar con atención a los vecinos de Green Town para descubrir la riqueza del universo entero en los detalles cotidianos.

Acompañar a los hermanos Spaulding en sus aventuras significa viajar al tiempo mítico de la infancia. Un tiempo que, más que una época pasada, es la zona oculta e indisponible de la subjetividad, el lugar nuclear de lo mistérico y lo fantástico en el adulto, es decir, de la fábrica de alteridad. Por ejemplo: calzarse unas zapatillas nuevas y pensar que vas a conquistar el mundo; averiguar que papá o el abuelo no lo saben todo; desconocer adónde te diriges pero tener la inquebrantable certeza de que nadie podrá detenerte; o preguntarte «¿cómo voy a cazar una araña de agua si no lo pruebo?»

Pero también es el tiempo del terror y el frío que causa la cercanía de la oscuridad, resto de lo inexplorado; encontrar al abuelo en su ataúd o el vacío en los ojos de la hermanita. En el que uno puede sentir cómo la Tierra gira bajo la cama; notar la ausencia de muros que delimiten el hambre insaciable de la noche; y rogar los brazos sostenedores de una madre. De enfrentarse a la negrura de "La cañada" donde se esconde la Muerte, el Solitario intangible, el ogro -o la soledad-, el estrangulador agazapado, ¿criaturas anónimas de otro planeta? Los delirios secretos y autodestructivos de un pueblo (de una civilización) y la comprensión de que todos los hombres tiemblan y que a menudo sólo contamos con nuestro propio corazón.

¿Por qué un científico decide inventar una Máquina de la Felicidad? ¿Qué efectos producirá en su conciencia comprobar las consecuencias que tiene en su familia? Una anciana contempla -sin poder impedirlo- cómo unas niñas le roban un anillo, un peine y una fotografía de cuando era pequeña, y a cambio, ellas le devuelven el más valioso y bello de los regalos. Atónitos y encantados, Douglas y sus amigos se dan cuenta de que cuanto más escuchan hablar a la Máquina del Tiempo del coronel, más cosas nuevas ven cuando abren los ojos y miran a su alrededor. La señorita Loomis, memoriosa trotamundos, es capaz de hechizarte y hacerte viajar a cualquier ciudad que sueñes visitar conjurando sus recuerdos con palabras. En fin, a uno le dan ganas de sumarse a los niños que atraviesan estas páginas y correr ferozmente como en un enjambre de meteoros. Porque estar en este mundo es algo de una rareza extrema, y cuando se ha perdido miedo a la muerte, la vida es realmente interesante. 